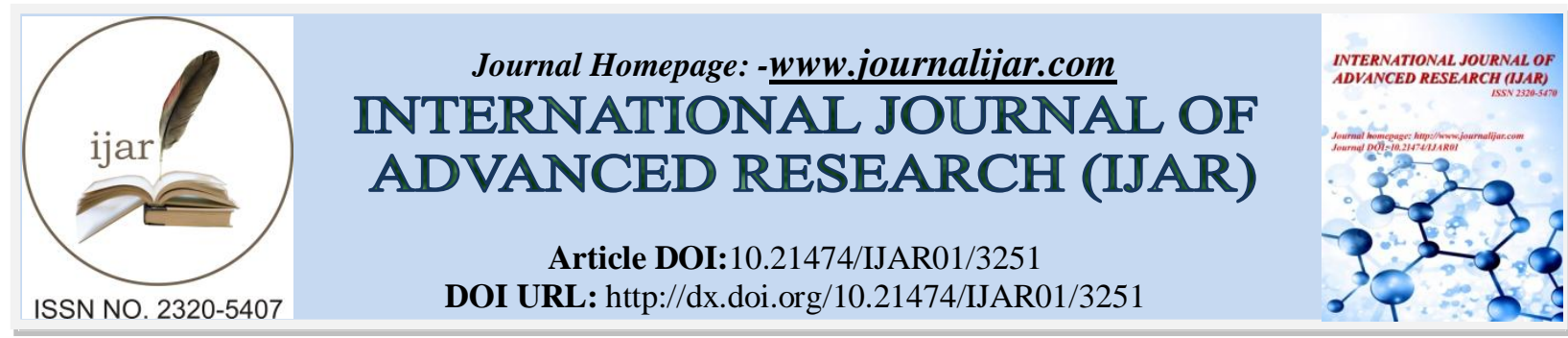

RESEARCH ARTICLE

\title{
RACE IN THE BLUESTEYE BYTONI MORRISON
}

ASST. Lecturer. Salam Hussein Yahya.

Department of English, CihanUniversity, Sulaimani.

\section{Manuscript Info}

Manuscript History

Received: 26 December 2016

Final Accepted: 30 January 2017

Published: February 2017

\begin{abstract}
The Bluest Eye, a novel by Toni Morrison, uncovers the deplorability of excellence in the public arena. Living in Lorain, Ohio in 1939, a 11 year old African American young lady Pecola Breedlove longs for the 'bluest eye', which she connects with a superior life where grown-ups wouldn't take a gander at her with a withdrew look and youngsters wouldn't taunt her. Drinking milk from a Shirley Temple container and picking 'Mary Jane' confections for the traditionally wonderful young lady enriching the wrapper, Pecola demonstrates her yearning to one day have her family turn into the encapsulation of the "Dick and Jane" family. A long way from her optimal, Pecola's family battles to have any feeling of affection live in their home. Both Mr. what's more, Mrs. Breedlove physically mishandle each other, and later on, Pecola is sexually manhandled by her dad, the peak of the story. At the point when her dad is in prison for an alternate wrongdoing, her family is part up. She then goes to the MacTeers' more steady home where Pecola turns out to be practically similar to a sister to the MacTeer young ladies, Frieda and Claudia. In the long run, Pecola's implausible wish gets the best of her, and she goes crazy, trusting she has the bluest eyes. Since she doesn't have blue eyes (she was deceived by malevolence Elihue, or Soaphead Church), individuals are not ready to see them, so she closes they are quite recently jealous.
\end{abstract}

Copy Right, IJAR, 2017,. All rights reserved.

\section{Introduction:}

The Bluest Eye is Toni Morrison's first novel, a book proclaimed for its fruitfulness of dialect and boldness of creative energy. African-American writing is created by the authors of African plummet living in the United States. It bargains chiefly with subjection, disparity, bigotry, sexism, classism, social conflict, and so forth. It takes after the old stories custom of narrating and incorporates oral structures like spirituals,sermons, gospel music, and so forth. Rigging up in the creator's girlhood main residence of Lorain, Ohio, it portrays the tale of dark, eleven-year-old Pecola Breedlove. Pecola appeals to God for her eyes to turn blue with the goal that she will be just as lovely and dearest as all the blondie, blue-peered toward children in America. In the harvest time of 1941, the year the marigolds in the Breedloves' greenery enclosure don't blossom. Pecola's life does change- in excruciating, decimating ways. The Bluest Eye stays one of Tony Morrisons' most intense, exceptional books and a critical work of American manufacture

The Bluest Eye is a harst warning about the old consciousness of black folks attempts to emulate the slave master. Piccolos request for more money and better house or even for more sensible parents; her request for blue eyes 
something she never wins. Morrionsdoes not have to recite the tale of three hundred years of black dominance by white culture for us to be mindful of this history of American Blacks, who have been victims in his calamity. The self hatred that is at the core of Pecola's character affects, in one stage or another. Here we explore and analyze Toni Morison's novels, in terms of the way to show the variability of Black feminism as characterized by the novelist who respond to the common sexist and racist context. Toni Morrison is a literary giant of the 1980s and 1990s and over all famous for being both a woman and an Afro-American. In her works, she has explored the experience and roles of black women in a racist in a male dominated society. In the center of her complex and multilayered narratives, there is the unique cultural inheritance of Afro-Americans. Her works also express the influence of Afro-American folklore, songs and women's gossip. In her endeavors to map these oral art forms into literary modes of theatrical performance, Morrison has created a body of work informed by a distinctly black sensibility while drawing a reading audience from across racial boundaries.

American Racism, ethnic American writers show their shared concern in their composition. The first body of ethnic writing to emerge. African American literature presents some of the most revealing investigations of racial discrimination. Early in the $19^{\text {th }}$ century, slave narratives recount the dehumanizing effect of slavery. In probability, the period most famous African American text, The Narratives of Fredrick Douglass, an American Slave, written by himself (1845). Fredrick Douglass, born into slavery in Maryland details his own experience of slavery and articulates his dignity as a man. Refusing details his own experiences in slavery and articulates his dignity as a human being. Refusing to submit himself to his master, he declares, "You have seen how a man, was made a slave, you shall see how a slave was made a man." Although by a century later slavery is no longer present, racial discrimination still intrudes upon every aspect of the lives of African Americans and positions them as "Invisible Men". Ralph Waldo Ellison's Invensible Man (1952) portrays a quest for individuality within the organization of American racialism. Ellison's unnamed black narrator's search for self-definition begins with an indictment of racial favoritism. To invisible, understand, simply because people refuse to look me." Morrison also writes from a feminist perspective describes how racism defines standard of beauty that militate against blacks, women especially and leads to tragic outcomes. That black is not beautiful has been regulated by European standards of blond, blue eyed stunner. In Morrison's novel the child Pecolas obsession with Shirley Temple and a desire to deliver "the bluest eyes" cause her to fall into madness. Her tragic story, Morrison illustrates another kind of soul-killing impact of American racism on African Americans. Founded on the same instance, John Okada's No No Boy (1957) here Neglection by the American dominant public and unwelcome in the Japanese American community for nearly two decades after publishing. The disfiguring effect of racial discrimination on the individual soul, the family, the Japanese American community, and other ethnic Americans prevails throughout the novel. This novel shows that blacks, Japanese, Chinese, Mexicans, Filipinos, and goes all strive for recognition as complete beings, namely as Americans, but so far few are able to cross the unseen walls constructed by racism. (Emanuel, 400-443)

The Black female body is the hottest thing. White men secretly revel in it, not only buying, trading, and wrapping it, but also assuaging the need and desire or mother's milk with it. Historically relegated to the auction block instead of the plinth, the black female body has been built at the ugly end of wearisome western dialectic; not frightened, but profane, not angelic but demonic, not fair lady but ugly dark. Only with her male counterpart, the black woman has belonged to one of those races "perceived as more animal like, and less godlike". One of the most potent and successful reappropriators of black representation is Toni Morrison,

In the Bluest Eye, this culturally mandated fracture is the impetus for what Pecola experience as disintegration or self-erasure:

"Please God," she whispered it the palm of her hired man. "Please make me disappear." She pinched her eyes close. Little parts of her body faded away. Now slowly, now with a rush. Slowly begin again. Her fingers went, one by one; then her arms went out all the way to the elbow. Her feet now, Yes that was decent. Her legs were restless and tired all at formerly. It was the hardest above the second joints. She bore to be really still and pull. Her stomach would not exist. But finally it, likewise, died out. Then her chest, her neck. The facial expression was hard, too. Almost done, almost only her tight, tight eyes were set aside. They are always on the left.

The pain tightened eyes remain witness to the horror - a company in which the white female body gives more prominence than a black woman. Already "a minority in both caste and class. Piccolo can't even take pride in, the 
main thing she can take her physical structure. For with few limited fonts, others affirm the undesirability of her life. Henceforth the reason Yacobowski did not see neither her body, nor the face, when Pecola had come to buy treats. At the point when Yacobowski had come to America, he adapted not to appear at the textual mode, nor the variety of dark masses. Morrison herself remarked in the thereafter to the novel, by the "Disguise of suspicions of unchanging inadequacy beginning with an outer expression. (Michiel, Vennessa, 195-200)

In The Bluest Eye, Pecola Breedlove is dealt with gravely both by the white people and dim cloned individuals. Indeed, her mom, Pauline Breedlove detests her for being dim, filthy, and dismaying. Her dad Cholly Breedlove is a drunkard. He misuses Pauline and Pecola physically, rationally, and inwardly. Pecola begrudges the white young ladies with blue eyes who are dealt with mercifully by the universe. She begs God to give blue eyes. She believes that the itinerary in which the world sees her will change on the off chance that she gets blue eyes like white young ladies. Towards the end of the novel, she gets blue eyes, yet at the expense of losing her brain. Frieda MacTeer, Claudia MacTeer, and Pecola Breedlove are all closely knit friends and all go to the same school. Piccolo goes to Frieda's home, and Frieda issues her bread rolls and milk. Pecola is not inspired by the milk, however the 'blue-andwhite Shirley Temple mug'. She drinks three or some milk just to understand and grasp the Shirley Temple glass. Mrs. master reprimands Pecola in a roundabout way for drinking an excessive quantity of milk. Pecola and Frieda talk about how "adorable" Shirley Temple is. Claudia doesn't care for the discussion in light of the fact that she loathes Shirley. She doesn't begrudge her white skin and blue eyes. Yet she had feelings her for hitting the dance floor with Bojangles, who is her most loved uncle.

The entire Breedlov clan has their troubles as Morrison tells us. Cholly Breedlove deserves attention for the special way he channels his double consciousness. Unlike his daughter Pecola.Cholly seems to be largely unaware of the forces shaping him. We see several instances where Pecola longs to be free of the white ideologies oppressing her, but Cholly and the rest of the clan "took the ugliness in their hands...and went about the world with it". Morrison tells us at the outset that Cholly's particular way of giving way "about the world" is in a state of inebriety, and we can read his drunkenness on both the literal level and the degree of his awareness. Most interaction that Cholly has with other characters occurs when he is lifted up. The first time we meet Mr. Breedlove, he "had come home drunk". We quickly find out that Cholly's alcoholism "relieved the tiresomeness of poverty... gave them the stuff they need to get their lives tolerable". The numbing properties of Whiskey are metonymies drunkenness numbs Cholly's violent outburst as well as his awareness of his own dual-consciousness. Morrison arrives at his clear when she composes. "Nothing Nothing... interesting him mow. Not himself, not other people. Only in the drink was there some break, some floodlight, and when the closed, there was oblivion".(Michele, 25,26)

Unlike the dark girls like Pecola, Claudia harts the black individuals' admiring and patronizing the white girls. Thus, she hates white young ladies and white dolls. At the point when black young girls appreciate and White Dolls with blue eyes and blonde hair, Claudia looks at the white doll's nose, blue eyeballs, and yellow hair to figure out 'what it is in them at all the world said is adorable'. Being unbiased and reasonable, she doesn't discover anything other than 'a mere metal roundness' in the white dolls. Claudia destroys white girls and ill-uses white young ladies. She needs to realize what makes individuals appreciate white young ladies and say "Awwwww" and overlook dark young ladies in the city. She unequivocally accepts that dim young ladies are as wonderful as white young ladies.

At the point when everyone had hatred and hate against Pecola for her darkness, Frieda and Claudia adore her and give her great fellowship and enthusiastic backing. Their white neighbor Rosemary Villanucci spies the young ladies and make incessant grumblings about them to their mom. Frieda and Claudia figure out how to reprimand or beat the white lady to take revenge. Claudia has a ton of sensitivity for the Breedloves who experience the ill effects of self-loathing and twofold consciousness. She illuminates that they live in a storefront not in the perspective of their dejection, yet since they feel that they are revolting. "Their dejection is standard and stultifying; it is not intriguing. Yet their unpleasantness is surprising." She needs to find where their revolting lies however couldn't find the source. She further says, "It begins from conviction, their conviction. It is generally as aall knowing master master had given everybody a cover of abnormality to wear, and they had each recognized it without request."

Whiteness as the quantity of beauty had become so entrenched in American club that many African Americans were negatively influenced by these measures of physical attractiveness based on skin color, which they could never reach. The community in the novel values light skin over dark skin, as typified by the "dream child" Maureen Peal. Morrison depicts the self-hatred that had become deeply rooted in many of the community members and reveals the way African-American women have been taught to hate or devalue their own bodies or physical properties. The 
reference in the novel often takes this hatred out on their kids. Geraldine, ashamed of her blackness, calls Pecola a "nasty little black bitch," and Pecola's mother exhibits more love for the white daughter of her employer than for her own children. (Amy, 36)

Pecola Breedlove has an inner urge for people to love her as they tend to love white girls. She goes to the candy shop, seeing Pecola the business person looks at her furiously and this makes her beautiful. She feels seeing her darkness the business person hates him. "It has an edge; some place in the base top is the abhorrence. She has seen it prowling according to all white individuals. So. The dislike must be for her, her blackness." She buys Mary Janes confectionery and appreciates the excellence of the white young lady imprinted on the wrapper. She eats the confectionery as though she is eating her eyes. She needs to be as delightful as Mary Jane. Her enthusiasm for blue eyes and white skin is depicted indecently by the storyteller: "Three pennies had purchased her nine dazzling climaxes with Mary Jane. Beautiful Mary Jane, for whom a treat is named."

The Theme involving the ingestion of whiteness is too clear in Pecola's selection of candy from Yacobowski's store. She buys Mary Janes. Even the innocent act of buying candy becomes an opportunity for racial self-bitterness and self-deprecation. Something as presumably benign as a candy wrapper functions as a site of white cultural semiosis. Even as Pecolas is rejected and denigrated by the power embedded within Yacobowski's gaze, whose eyes, equally I have noted are blue, she seeks the power of Mary Jane's blue eyes through a procedure of "Symbolic Cannibalism." Blue eyes are menacing and still they also stand for safety and comfort. Blue eyes constitute a metonymy for white hegemony as this is expressed through White cultural aesthetic ideals. GunillaTheanderKester argues that "blue eyes" stand as a Pars pro toto, a Synecdoche for a clean little girl whom a racist culture would consider beautiful. Like the innocence of the milk, the slice of candy is believed to deliver power to bring about a true state of ontological change in Pecola, a change from Black to White from a state of "racializedsomatophobia" to a state of clean somatic comfort and "normalcy"(George, 183-227)

At the point when dark young ladies are disfavored, lightly-cleaned rich young lady Maureen Peal is viewed as prevalent in the school. Frieda and Claudia despise her and attempt to discover errors in her. All the others in the school appear to regard her in her light-shaded skin. "At the point when Teachers approached her, they grinned encouragingly. Black young men didn't trip her in the lobbies; white young men didn't stone her, white young ladies didn't suck their teeth when she was allocated to be their work accomplices; dark young ladies moved to one side when she needed to utilize the sink as a part of the young ladies' can, and their eyes kneeled under sliding lids"

Maureen Peal saves Frieda, Claudia, and Pecola from the abuse of school boys who feel contempt and disgrace for their own particular darkness. Pecola is pulled in towards her while Frieda and Claudia get to be furious at her remark that they are dark - "Dark? Who you calling dark?"'You!" "You think you so adorable!" They attempt to hit Maureen and yell her epithet "Six finger-canine tooth-meringue-pie!" They abhor her for being light-cleaned, talking about obscurity to them, and discussing exposure to Pecola.

Geraldine's is a rich, slick dark lady who adores just her Cat for its 'cleanliness'. She educates her child Junior to play just with white children and not niggers. "She had disclosed to him the contrast between minorities, individuals and niggers. They were effectively identifiable. Minorities individuals were flawless and calm; niggers were messy and uproarious." According to her, she and her family fit in with the first gathering as they are rich and slick. Despite the fact that Junior needs to play 'Ruler of Mountains' with his dark companions and feel the soil while moving down on the dirt, he abstains from everything for the purpose of 'cleanliness'. At first he prefers Bay Boy and P. L. Gradually he persuades himself that Ralph Nisensky is beneficial for him and stays doing nothing. Junior needs to be a nigger, however, he is forced to carry on like a white kid. He yearns for genuine friendship from his mom and despises her feline. Getting baffled, he adds to the propensity for mishandling defenseless dark youngsters. He calls Pecolato his home and tosses his mom's feline on her. He appreciates a considerable measure by tormenting her. He giggles generously on seeing her getting alarmed and crying. At the point when his mom Geraldine goes into the house, he advises her that Pecola tries to murder her feline. She gets appallingly irate and yells, "You dreadful minimal dark bitch. Escape from my home." Pecola is profoundly insulted by the physical and verbal misuse in the rich dark family unit of Geraldine.

Frieda and Claudia go to see Pecola in the white family unit where Pauline Breedlove acts as a cleaning specialist. Pecola gets to be dismal while listening to a white kid calling her mom 'Polly', actually when Pecola calls her mom Mrs. Breedlove. Out of resentment or anxiety, she drops the silver dish with bubbling berry shoemaker on her feet. 
As opposed to applying solution on her blaaze or supporting her, Pauline beats her and cautions her to leave the room quickly. She reveals her for making her "clean" room "filthy" with berry shoemaker. "Insane blockhead... my floor, a mess... look what you... work get on out now out insane... my floor, my floor... my floor." A little young white girl in the white family cries and Pauline persuades her by saying that she will make crisp berry shoemaker for her. She expresses "honey" words to the white kid in the wake of tossing words like 'spoiled bits of pieces of fruit's all alone dark kid and her dark companions. Pecola's mom, Pauline Breedlove herself is a casualty of twofold cognizance. Her feeling of excellence is broken by her twisted foot and a broken tooth. At the point when Cholly has intercourse with her, she feels youthful, really, solid, and capable. After marriage, they go to an inaccessible spot for work. She becomes frustrated with Cholly's darkness and conduct. She builds up the enthusiasm for purchasing unreasonable garments to look for consistent consideration from her neighbors. She loves white individuals actually when she recollects that her conveyance involvement in a hospital where a white specialist clarifies his younsters that dark ladies 'convey immediately and with no torment... much the same as horses.'

She clarifies that it doesn't imply that dark ladies don't have torment as they don't 'hoop or holler' in agony as the white ladies. Being pulled in towards whiteness, she turns into a servant, dismisses her home, youngsters, and spouse, and discovers 'excellence, arrange, cleanliness, and applause' in her white expert's family. Pecola's dad Cholly Breedlove is a vagrant raised by Aunt Jimmy. He is constrained to have intercourse with his better half Darlene before two white men who come looking for their pooch amid chasing. He accepts that the white men are solid and outfitted, and his displeasure with them may crush him until the end of time. So he redirects his annoyance towards the dark young lady Darlene. Later he looks for honest nation cherish in Pauline. Pauline, who venerates magnificence and cleanliness cherishes Cholly as she feels lovely, solid, and effective in Cholly's vicinity. Gradually she loathes him for his unclean conduct. Being pulled in towards 'whiteness and cleanliness', she couldn't love the 'dim and messy' Cholly completely and turns into a housekeeper in a white family. Cholly turns into a boozer and torments Pauline and Pecola.

'Dirty Black' Cholly, father of Pecola rapes her, while the 'clean old man' Soaphead Church abuses young ladies who go to the congregation. Soaphead Church is a 'cinnamon-peered toward West Indian with gently seared skin' from a blended set of relatives. His unique name is Elihue Micah Whitcomb. He is a cynic, however he acts as a minister and pronounces himself as the 'Peruser, Adviser, and Interpreter of Dreams'. He despises 'tissue on substance'. He does not have the bravery to turn into a 'gay person'. He loathes "savagery" and 'homosexuality'. "His considerations slowly settled on those people whose bodies were minimum hostile kids... Since young men were offending, terrifying, and resolved, he further restricted his diversions to young ladies. They were generally reasonable and often enchanting." Seeing the activities young girls don't regret for, rather, he defends his activities by saying that the young girls appreciate the same. With young ladies it is all clean and great and neighborly."

The Bluest Eye depicts not only the wounds caused by inter- and interracial shamming but also the horrors of the father-daughter incest. But although "The Bluest Eye" depicts the shameful family secret of an incestuous rape, it also is caught up in a form of denial. Indeed, Morrison has described the rape as "almost irrelevant," insisting that she wants readers to "look at" Cholly and "see his love for his daughter and his powerlessness to help her pain." Cholly's "embrace, the rape," in Morrison's words, "is all the gigt he has left If Morrison, in writing the novel, found herself thinking the "unthinkable as she worked out the incest secret that lies buried at the hart of "The Bluest Eye", she also ran into difficulties as she felt the need to provoke the reader sympathy for Cholly, despite what he does to his daughter. By insisting that the "pieces of Cholly's life" can be rendered "coherent only in the head of a musician" who can connect together the various fragments of Cholly'slife, the narrative invites the readers to focus on the connection between Cholly's fragmented trauma narrative and his rape of Pecola: that is, to understand Cholly's rape of Pecola, the reader must understand Cholly's traumatic sexual initiation as an adolescent. The fact that Morrison chose to tell the rape from Cholly's point of view and that Morrison'snarrative, in part, endorses Chooly - for he is, in Morrison's own description, one of her "salt tasters," a "fearless" and "lawless" character suggests the hidden way in which the novel position readers not only with the humiliated victin but also with the humiliator, the shamed, engaged father who projects his own shame onto his daughter and thus acts as an unwitting agent in the white society's humiliation of the vlnerablePecola. Although Morrison wants to elicit reader sympathy for Cholly, she also invokes the pernicious - and shaming - racist image of the black man as rapist in this scene. And she risks shaming her readers as she breaks the taboo on looking and positions her readers as voyeurs of the incest scene. 


\section{Race in Toni Morrison's Novel:}

Through her book, The Bluest Eye, Tony Morrison demonstrates a great sample, to the dark group and to the world, how social orders supremacist and false convictions on magnificence and self worth can do genuine damage if accepted and taken to heart. What more honorable case to demonstrate these repercussions than Pecola Breedlove, a detached and susceptible little girl who, lacking self regard and parental guidance, gets tied up with everything without a second thought and trusts herself to be one of the blackest ugliest young ladies of all time.Morrison utilizes Pecola and the theatrical roles as a part of pecolas life to investigate the risks included in the dark group and all groups alike to get linked up with the thought that white, and just white had been splendid.These social measures created by the media and white people groups saw at the time were idiotic and one-sided, yet where genuinely widespread in America just about then. These social norms were unnecessarily harming individuals, and Morrison needed to demonstrate the agony that can emerge from getting tied up with those beliefs.(borey) Morrison tells that she got the innovative motivation for the Bluest Eye from a colleague she had in elementary school. The young lady longed for blue eyes, and Morrison saw that in longing for blue eyes, she was longing for an alternate character other than grim. She was bothered with who she was and it made Morrison consider excellence and how this new lady had come to feel sub-equation. She asked to dig into the internal workings of how somebody could come to accept that their race of individuals were not lovely, or just delightful on the off chance that they took after whites, on the reason that only whites were excellent. She needed to stick to reality, about beauty, our general public and our reality. She asked to draw down to the reasons why individuals could get linked up with a lie that they are not lovely in the effect that they are not clean.To come to the reasons why individuals would take a part in abusing themselves. The report is based on a young lady named Pecola Breedlove, who arises from a poor, grieved him She and her family are pathetic and they seem to regard themselves as appalling. The story compasses the course of a year and is divided off into four seasons, Autunm, Winter, Spring, Summer. Pecola's Mother treats her own family ineffectively while being a phenomenal servant to a white family, and her dad, Cholly is a savage, furious inebriated. The larger portion of the Breedloves are viewed as dire and they have entirely grown to acknowledge themselves as out and out monstrous individuals. The overture to the story recounts how Pecola will be saturated.

Piccolo goes to Soaphead Church with the wish of getting blue eyes. He guides her to kill a powerless, filthy puppy in his proprietor's home. Pecola runs with the fulfillment that God will allow her wish as she has done what the minister has requested that she do. In the in the interim, she is impregnated by Cholly. As opposed to sympathizing her, the entire neighborhood reviles her. "Can't resist the opportunity to be.Should be a law: two monstrous individuals bending over like that to make all the more appalling. Be in an ideal situation in the ground." Frieda and Claudia can not completely comprehend the circumstance. Anyway, they feel sorry for Pecola and petition God for her tyke. 'More firmly than her affection for Pecola', Claudia needs the child to survive "just to balance the widespread adoration for white infant dolls, Shirley Temples, and Maureen Peals". Amid her pregnancy, Pecola gets to be rationally shaky. She accepts that God has allowed her blue eyes through Soaphead Church. She continues conversing with her fanciful companion about her blue eyes. In view of her unlawful pregnancy, her mom and neighbors don't take a gander at her or converse with her. Yet she believes that they dodge her as they are envious of her blue eyes. She doubts whether her nonexistent companion is likewise envious of her blue eyes. The Bluest Eye presents a disturbing account of Cholly's rape of Pecola and then partially denies what is has described by insisting in the closure that Cholly loved Pecola even though his "touch was fatal" for the "love of free man is never safe." (Bouson, 39,42)

She asks whether her eyes are bluer than those of Joanna, Michelena, and other white women. Inspite of Frieda and Claudia's prayer and sacrifice, Pecola's still-born child dies. Pauline Breedlove moves to the edge of the town. She keeps doing housework. The dirty, dark Cholly dies in the workhouse. Claudia remarks that Cholly adores Pecola a great deal. In any case his affection is lethal. "He, at any rate, was the person who adored her enough to touch her, conceal her, give something of himself to her. Yet his touch was deadly, and the something he issued her filled the grid of her distress with death." She includes that "Affection is never any better than the significant other.

The Bluest Eye begins with a black girl's entry into the procreative cycle; when Pecola first begins menstruating, Frieda reverentially informs her that she can now have a baby. Pecola's reproductive capacity, however, does not enable her to sustain the continuity of the natural cycle. We have already noted the disjunction between the movement of Peola'ssory and the movement of natural cycle: Pecola begins menstruating in autumn, is raped in spring, and givs birth a stillborn baby in summer. Nowhere in the novel are black women celebrated s biological embodiments of the natural continuum; rather the reproductive function of the black woman character consistently goes awry, as with Pauline's rejection of her own daughter in favor of her mistress's daughter, Geraldin'stransference 
of maternal love from her son to her cat. Gubar says that Pecola is rejected by her mother and remains a victim as well as a symbol of the dying land. (Madhu, 43)

Evil individuals adore mischievously, rough individuals love roughly, frail individuals cherish pitifully, blockheads love moronically, yet the adoration for a liberated person is never protected." She says that the darling alone appreciates and the adored one endures. "The significant other alone has his endowment of adoration. The adored one is shorn, killed, solidified in the glare of the beau's internal eye." After all these episodes, Frieda and Claudia never see Pecola. They feel miserable that they wish and penance has turned into a waste and misgiving that 'its much, much, much past the point of no return'. Claudia mirrors that the minimal, dark, monstrous young lady has made the area look excellent.

Morrison's selection of the name "Breedlove" in "The Bluest Eye" is significant in various ways. Breedlove is the figure of the Madame C.J. Walker, the foremost African American millionaire, who had built her fortune inventing hair straighteners and skin Lighteners for blacks in the late nineteenth century. The Breedloves' acceptance of an outward evaluation of themselves breeds, in fact, a self hatred that manifests in diverse ways, from Pecola's desire for blue eyes, to Pauline's preference for the little white daughter of her employer, to Cholly's rape of his own daughter. There is yet, another sense in which Morrison's employs the name "Breedlove" as a signifies of the slavebreeding culture with its short-circuited desire and the desire for consensual sexual intimacy tat drives both Pauline and ChollyBreedlov. Pauline's desire appears at the conclusion of her first person stream-of-consciousness narrative in the cast of "musing, idle thoughts, sometimes full of old dreaminess":

His face is next to mine. The bed springs sounds like them crickets used to back home. He puts his fingers in mine, and we stretch our arms out wide like Jesus on the cross. I hold on tight....I know he wants to come first. But I can't. Not only he does. Not Until I feel him loving me, just me. Sinking into me. Not until I know that my flesh is all that be on his mind. That he couldn't stop if he had to. That he would die rather than take his thing out of me. Of me. Not until he has let go of all he has and gave it to me. To me.To me. When he does I feel powerless. I be strong I be pretty, I be young.

The erotic equation of sexual desire with the power to be desired reenacts the erotic circuit of the Song of songs. Rather than position women as an object of male desire, the woman here rewrites herself as the subject of her own narrative. Yet Pauline cannot bring this narrative moment into the cultural symbolic to the novel, and it si this failure that opens the space for Cholly Breedlove's rape of his own daughter Pecola. Indeed the novel begins with the realization of the transgression of the incest taboo, the original fall that drives desire in the novel.(Adrienne, Justine, 159)

"The greater part of our waste which we dumped on her and which she consumed. What's more, the majority of our magnificence, which was hers first and which she provided for us. Every one of us- -all who knew her- -felt so wholesome after we cleaned ourselves on her. We were so lovely when we stood on the back of her offensiveness. Her effortlessness adorned us, her blame purified us, her agony made us gleam with wellbeing, her cumbersomeness made us think we had a comical inclination. Her incoherence made us accept we were smooth. Her neediness kept us liberal. Indeed, her waking dreams we utilized -to quiet our own bad dreams. What's more, she let us, and in this manner merited our disdain." Claudia remarks that the entire neighborhood feels content and calmed on seeing the sufferings of Pecola. Twofold cognizance offends, contemplations, and conduct of the dark individuals. They create self-loathing and start to ache for whiteness. They love white individuals despite the fact that they are mishandled or offended by them. Pecola is loathed by white individuals, detested by her own mom, assaulted by her own dad, tormented by dark kids, and reviled by her dark neighborhood. She is left by Frieda and Claudia as well. The minimal dark young lady who is a casualty of twofold awareness needs to get blue eyes just to be dealt with merciful like the white young ladies. She is sold out by the white individuals, as well as by her dull cleaned folks and neighbors who themselves experience the ill effects of twofold awareness. Rationally unhinged, she lives alone with the fulfillment that she has got the blue eyes. "Nobody else will see her blue eyes. Anyway, she will. What's more, she will live cheerfully ever after."

Pecola's experience in Toni Morrison's The Bluest Eye exemplifies the multiple oppression of black women on the bases of gender, race and class. Charged with their slave heritage at the background, humiliated as members of a subjugated minority class and customized due to their race, black feminity causes Pecola's life to culminate in 
obsessive self and race-hate. Raised up in a highly consumer-based capitalist society, Pecola becomes a victim of the Body Politics of the dominant Western Ideology, which has standardized the norms of feminine beauty in the gloomy-eyed slenderness of the white woman.; Regarding Blue-eyed beauty as the only norm of acceptability in American society, she is bewitched in a trap of eating disorder proceeding from several psychological and sexual frustrations. While her outcast-ness gains further psychological and familial forms with her victimization in her own father, ensuring in her pregnancy, her yearning for for blue eyes leads Pecola to be cooked by a child abuser spiritualist in still another sort of exploitation. Made to believe by him she is condemned to live out all alone in her home turned up outside the town as a physical mark of her outsiderness.(Yasmin, 469)

\section{Conclussion:}

Toni Morrison is an amazing women's lobbyist figure in American Advanced Literature. Her capability lies in the photograph of dim society in America. Her female characters can be onlookers in supporting her work. Morrison shows her circumlocutory stun at having sexist and supremacist considerations in relationship with white social occasion. She focuses on a moral, social view as a bunch for the entire dull get-together; a get-together which needs societal sponsorship and imperativeness.

As the parts of race, social class, enslavement, and sex are therefore essential in Toni Morrison's books, social realists and faultfinders enthused about social issues examine her books from a few reasons for appraisal. Abusing the beforehand specified events in her fiction, Morrison has made perusers mindful of the catastrophes that African Americans face in their lifetime. Morrison has punctured into the brains of her cases, uncovering their considerations brilliantly. Her works can be an exceptional organization to impact the place of blacks and particularly diminish females from edge to center. Also, the imperativeness of Morrison's fiction falls on its vitality to consolidation issues of race, sexual introduction, sex, and social class meanwhile. The tip around her books is that paying little heed to the way that issues of predisposition and enslavement are focal, she has not expelled diverse subjects. That is, Morrison's books indicate general truths about the human condition and that is the reason her fiction is attracting both white and dull social gatherings of the giant unwashed.

In The Bluest Eye Morrison has shown the impacts of white culture on Dark individuals. In this novel Pecola is a photograph of out and out disintegrating as she faces both between inclination also, intra-predisposition. Other than she is kept from securing her mom's family relationship, is trapped by her father, and holds out a desperate rootless proximity. She is instigated that there is develop way out of each one of these matters - that is to have light blue eyes. Nevertheless, before the target she is left basically with an irreversible conclusion a hardship.

\section{Reference:}

1. Anthias, Floya, and Nira Yuval-Davis. Racialized boundaries: Race, nation, gender, colour and class and the anti-racist struggle. Routledge, 2005..

2. Baker, Russell, and William Knowlton Zinsser, eds. Inventing the truth: The art and craft of memoir. Houghton Mifflin Harcourt, 1998.

3. Bennett, Michael, and Vanessa D. Dickerson, Eds. Recovering the Black Female Body: Self-Representations by African American Women. Rutgers University Press, 2001., Page No. 195-200

4. Bhachu, Parminde, and Sallie Westwood. Enterprising women: ethnicity, economy and gender relations. Routledge, 2004..

5. Bouson, J. Brooks. Quiet as it's kept: shame, trauma, and race in the novels of Toni Morrison. SUNY Press, 2000. Page No. 39 to 41

6. Dubey, Madhu. Black women novelists and the nationalist aesthetic. Indiana University Press, 1994. Page No. 43

7. Holmes, Michele. The Quantum Eye: Looking and Identity Formation in African-American Fiction. ProQuest, 2007.Page No. 25,26

8. Lentin, Alana. Racism and Anti-racism in Europe. Pluto Press, 2004..

9. Li, Stephanie. Toni Morrison: A Biography. ABC-CLIO, 2010.. P1-10, P31-58

10. Morrison, Toni, and William Zinsser. "Inventing the Truth: The Art and Craft of Memoir." R. \&. Baker, Inventing the truth: The art and craft of memoir. Boston, USA: Houghton Mifflin (1987)., 101-24.

11. Morrison, Toni. "The Bluest Eye. 1970." New York: Plume (1994).. 
12. Nelson, Emmanuel S. "PEDAGOGY AND US ETHNIC LITERATURES." Ethnic American Literature: An Encyclopedia for Students USA: ABC-Clio, LLC, 2015: Page No. 400-443

13. Sertel, YaseminGüniz. Female Outcasts. Indiana : Author House., 2014 Pg NO. 469

14. Seward, Adrienne Lanier, and Justine Tally, Eds. Toni Morrison: Memory and Meaning. Univ. USA: Press of Mississippi, 2014., Page No. 159

15. Sickels, Amy. African-American Writers. Infobase Publishing, 2010. Page No. 36

16. White, Evelyn C., ed. The black women's health book: Speaking for ourselves. Seattle, WA: Seal Press, $1990 .$. 